\author{
Dariusz Gardocki ${ }^{1}$ \\ Papieski Wydział Teologiczny w Warszawie \\ Collegium Bobolanum
}

\title{
Misja Kościoła — niezwykła zwykłość nauczania papieża Franciszka
}

Minęło już ponad pięć lat od momentu, kiedy to kardynał Jorge Bergolio został wybrany na następcę św. Piotra i przyjął imię Franciszek, które - można powiedzieć - stało się programem jego pontyfikatu. Zasiada on na urzędzie Piotrowym po wielkich papieżach takich, jak Jan XXIII, Paweł VI, Jan Paweł II i Benedykt XVI. Pierwszy z wymienionych papieży zwołał II Sobór Watykański. Paweł VI podjął się kontynuowania dzieła rozpoczętego przez swojego poprzednika po jego śmierci, by następnie zaangażować się we wprowadzanie w życie postanowień soborowych. Jan Paweł II z kolei wraz z Benedyktem XVI byli tymi, którzy — pierwszy jako arcybiskup, drugi jako teolog — uczestniczyli w obradach i pracach soborowych oraz mieli wpływ na ostateczny kształt i treść przynajmniej niektórych z dokumentów opracowanych przez sobór. Obaj poza tym już jako papieże „próbowali ustanowić autorytatywną interpretację soboru" ${ }^{2}$. Franciszek natomiast jest pierwszym papieżem, który nie tylko nie pochodzi z Europy, ale także nie był w żaden sposób osobiście związany z soborem, jak było to w wypadku poprzednich papieży. Można zatem powiedzieć, że jest on pierwszym papieżem posoborowym. Rozpoczął bowiem studia teologiczne w 1967 roku, a więc dwa lata po zamknięciu soboru. Niemniej jest kontynuatorem zarówno nauczania soborowego, jak i swoich poprzedników na urzędzie Piotrowym. Z drugiej zaś strony jest nie tylko spadkobiercą i kontynuatorem wcześniejszej tradycji, lecz także jej ,innowatorem, tzn. osobą, która przyjmuje krytycznie to, co otrzymała"’. Wskazuje jednocześnie na nowe perspektywy,

${ }^{1}$ Ksiądz dr hab. Dariusz Gardocki SJ, prof. PWTW — wykładowca teologii dogmatycznej; e-mail: darekg01@op.pl. ORCID: 0000-0002-5541-9154.

2 R.R. Reno, Dlaczego mam kłopot z Franciszkiem, „Znak” 754 (2018), s. 12-17, tu: s. 17.

3 J. Corkery, Francesco, erede e innovatore: un Papa Argentino e gesuita nella tradizione post-conciliare [w:] Dal chiodo alla chiave. La Teologia Fondamentale di Papa Francesco, a cura 
jakie pojawiają się przed Kościołem dzisiaj oraz na to, co może i powinien on czynić ${ }^{4}$. Jest papieżem, któremu ,powierzono wymagające zadanie wprowadzenia Kościoła w nowe duchowe rejony, w epokę radykalnego pluralizmu, globalnego połączenia się cywilizacji, kiedy jeszcze nie jest jasne, czy to połączenie doprowadzi ostatecznie do pokojowego i kompatybilnego współżycia czy do apokaliptycznego zderzenia cywilizacji”'. Jest ponadto papieżem zobligowanym do stawienia czoła obecnej sytuacji Kościoła charakteryzującej się poważnymi problemami, wręcz stanem kryzysu, u podstaw którego leży nie tylko wypaczanie i odchodzenie od istoty wiary chrześcijańskiej, lecz także brak samej wiary ${ }^{6}$.

Celem artykułu jest wyjaśnienie, na czym polega i w czym wyraża się oryginalność Franciszka i jego nauczania. W pierwszym punkcie zostanie omówiona nauka II Soboru Watykańskiego na temat misji i natury Kościoła. W drugim zaś zostanie przedstawiona recepcja nauczania soborowego i jego twórcze rozwinięcie przez Franciszka. W trzecim natomiast punkcie zostanie ukazana nowość nauczania papieża Franciszka.

\section{Nauka II Soboru Watykańskiego na temat misji i natury Kościoła}

II Sobór Watykański jest określany jako sobór duszpasterski a zarazem jako sobór Kościoła o Kościele?. Sobór ten chciał bowiem „Kościoła odnowionego duchowo z ducha Ewangelii, znajdującego się na drodze osobistego uświęcenia i reformy". Niewątpliwą zasługą soboru było to, że po pierwsze, dokonał otwarcia Kościoła na świat, zainicjował dialog z ludzkością i z innymi wyznaniami. Po drugie, zapoczątkował reformę Kościoła oraz odnowił rozumienie natury i misji Kościoła. Po trzecie, wskazał na potrzebę „badania znaków czasu i wyjaśnienia ich w świetle Ewangelii, tak aby Kościół mógł w sposób dostosowany do mentalności każdego pokolenia odpowiadać ludziom na ich odwieczne pytania"9. Po czwarte, zwrócił uwagę na potrzebę poszukiwania odpowiedniejszych spo-

di M. Tenace, Cittá del Vaticano 2017, s. 135-150, tu: s. 136. Tłumaczenie tu i w przypadku pozostałych cytowanych tekstów obcojęzycznych - D. Gardocki.

${ }^{4}$ Por. G. Whelan, Il metodo teologico di papa Francesco [w:] Dal chiodo alla chiave. La Teologia Fondamentale di Papa Francesco, a cura di M. Tenace, Città del Vaticano 2017, s. 113-133, tu: s. 113.

5 T. Halik, Pięć lat z Franciszkiem, tłum. K. Ćwiek-Rogalska, „Znak” 754 (2018), s. 6-11, tu: s. 8.

${ }^{6}$ Por. B. Łoziński, Zrozumieć Franciszka, „Gość Niedzielny” 39 (2018), s. 34-36, tu: s. 35.

7 Por. W. Kasper, Kościót katolicki. Istota, rzeczywistość, posłannictwo, tłum. G. Rawski, Kraków 2014, s. 28-29.

8 Tamże, s. 36.

${ }^{9}$ Sobór Watykański II, Konstytucja duszpasterska o Kościele w świecie współczesnym Gaudium et spes, 4 . 
sobów przedstawiania nauki Kościoła i głębszego poznania prawdy objawionej na drodze konfrontowania jej z aktualnymi wyzwaniami i problemami, jakimi żyje dzisiaj ludzkość ${ }^{10}$. Po piąte, mówił o konieczności zaspokojenia nie tylko potrzeb duchowych, lecz także społecznych i ekonomicznych, oraz podkreślał odpowiedzialność wszystkich ludzi za budowanie lepszego świata i nowego humanizmu" ${ }^{11}$. Po szóste, pokazał, że postęp ludzkości i to wszystko, co jest z nim związane i co służy budowaniu społeczności ludzkiej, nie jest czymś całkowicie obcym i obojętnym rzeczywistości królestwa Bożego ${ }^{12}$. Po siódme, przypomniał prawdę na temat tego, że Kościół w ludzkich ubogich i cierpiących „odnajduje wizerunek swego ubogiego i cierpiącego Zbawiciela" ${ }^{13}$ oraz określił zaangażowanie na ich rzecz jako służbę Chrystusowi. Po siódme, wskazał na Pismo Święte i jego studium jako na „duszę całej teologii”" ${ }^{14}$. Po ósme, dowartościował człowieka, historię, kulturę i świat stworzony, pokazując, że wymienione rzeczywistości mają ścisły i wewnętrzny związek z wydarzeniem wcielenia Syna Bożego, ponieważ Ten, stając się człowiekiem, ,zjednoczył się w pewien sposób z każdym człowiekiem [...] i stał się prawdziwie jednym z nas"15. Po dziewiąte wreszcie, ukazał istnienie jednego powołania całej ludzkości, które jest skutkiem i owocem zarówno wcielenia Syna Bożego, jak i śmierci Chrystusa za wszystkich ludzi ${ }^{16}$.

Obok zasygnalizowanych kwestii, które zostały zarysowane przez II Sobór Watykański i które zostają podjęte i wykorzystane także przez papieża Franciszka w jego nauczaniu, należy wymienić jeszcze problematykę dotyczącą rozumienia samego Kościoła i przede wszystkim jego misji w dzisiejszym świecie. Temat ten jest ważny, ponieważ pozwala dostrzec i zrozumieć rzeczywistą zmianę, jaka dokonała się za sprawą soboru w kwestii rozumienia Kościoła i jego misji, której kontynuatorem jest papież Franciszek. By móc dostrzec tę zmianę, potrzeba uwzględnić nie tyle poszczególne wypowiedzi soborowe, ile przede wszystkim „nowe kategorie przyjęte przez sobór dla wyrażenia źródła i misji Kościoła we współczesnym świecie"17. Jedną z takich zasadniczych kategorii jest zaproponowane przez sobór rozumienie Objawienia Bożego jako samoobjawienia i samoofiarowania się Boga Trynitarnego człowiekowi, które dokonuje się za pośrednictwem wcielenia Syna Bożego i zesłania Ducha Świętego po to, by Bóg mógł

\footnotetext{
10 Por. tamże, 62.

11 Por. tamże, 55.

12 Por. tamże, 39.

13 Sobór Watykański II, Konstytucja dogmatyczna o Kościele Lumen gentium, 8.

14 Sobór Watykański II, Dekret o formacji kapłańskiej Optatam totius, 16.

15 Sobór Watykański II, Konstytucja duszpasterska o Kościele..., 22.

16 Por. tamże.

17 G.L. Müller, Un'esperienza liberante: impulsi per la teologia della liberazione [w:] Dalla parte dei poveri. Teologia della liberazione, teologia della chiesa, a cura di G.L. Müller, G. Gutièrrez, trad. M. Castagnaro, G. Mazzillo, Padova 2013, s. 19-44, tu: s. 20.
} 
zostać poznany i przyjęty przez ludzi jako prawda, życie i właściwy cel historii ludzkiej, jak również po to, by On sam mógł przyjąć ludzi do wspólnoty ze sobą i uczynić z nich współuczestników swojej Boskiej natury ${ }^{18}$.

Drugą ważną kategorią jest to, że Objawienie Boże ma, według soboru, charakter osobowy, ponieważ Bóg osobowy objawia się osobom i przemawia do osób, co zakłada dialog i komunikację. Oznacza to, że Bóg zwraca się do osób, które jako istoty duchowo-cielesne włączone są także materialnie w obszar historii, kultury i społeczeństwa. Nauczanie soborowe wskazuje jednocześnie na to, że Kościół powinien czuć się odpowiedzialny za społeczność ludzką i powinien angażować się także w obszar świata pracy, ekonomii międzynarodowej, sprawiedliwości społecznej i pokoju w świecie ${ }^{19}$.

Przedstawione rozumienie Objawienia Bożego jest ważne $\mathrm{z}$ tego względu, że odzyskuje ono historyczny sens i wymiar Objawienia Bożego związany z wcieleniem Syna Bożego i z działaniem Ducha Świętego zarówno w Kościele, jak i w świecie. Wpływa ono poza tym na sposób, w jaki sobór definiuje naturę i misję Kościoła. Do natury bowiem Kościoła, która jednocześnie określa jego powszechne posłannictwo, należy bycie w Chrystusie ,jakby znakiem i narzędziem wewnętrznego zjednoczenia z Bogiem i jedności całego rodzaju ludzkiego" ${ }^{20}$. W słowach tych sobór pokazał, że zadaniem Kościoła jest pozostawanie na służbie zbawienia, które Bóg ustanowił historycznie w Jezusie Chrystusie i że zbawienie to z woli Bożej przez działanie Ducha Świętego stanowi „stałą zasadę historii ludzkiej i budowania społeczeństwa godnego człowieka"21. Zdefiniował jednocześnie w nowy sposób misję Kościoła jako bycie sakramentem zbawienia świata, przez co nadał katolickości Kościoła bardziej doświadczalny i oczywisty wymiar. Odtąd bowiem „my” Kościoła nie może już być określane i rozumiane na poziomie wyłącznie regionalnym lub kulturowym, lecz w kontekście świadomości wszystkich wierzących w świecie w Chrystusa jako stanowiących jedno „my”, jedno ciało i jeden Kościół. Konkretnie mówiąc, owo „my” Kościoła powinno być rozumiane jako realizowanie się Kościoła powszechnego we wspólnocie i w jedności z Kościołami lokalnymi i odwrotnie ${ }^{22}$. Takie rozumienie Kościoła jest tym, co umożliwia Kościołowi konfrontowanie się z wielkimi wyzwaniami współczesnego świata i pozwala na jego udział a zarazem na wnoszenie przez niego wkładu w budowanie społeczeństwa globalnego.

Ze zdefiniowanej przez sobór natury Kościoła wynika wreszcie relacja Kościoła do świata, która zostaje określona przez sobór jako ścisła łączność Kościoła

\footnotetext{
${ }_{18}$ Por. Sobór Watykański II, Konstytucja dogmatyczna o objawieniu Bożym Dei verbum, 2-6.

19 Por. G.L. Müller, Un'esperienza liberante..., s. 21.

${ }^{20}$ Sobór Watykański II, Konstytucja dogmatyczna o Kościele..., 1.

${ }^{21}$ G.L. Müller, Un'esperienza liberante..., s. 23.

${ }^{22}$ Por. tamże, s. 40-41.
} 
z całą rodziną ludzką. Łączność ta wynika - zdaniem soboru - po pierwsze $z$ tego, że wszystko, co przeżywają ludzie, przeżywają także uczniowie Chrystusa, a po drugie z tego, że zadaniem chrześcijan, którzy pielgrzymują do królestwa Ojca i są zjednoczeni w Chrystusie oraz kierowani przez Ducha Świętego, jest niesienie orędzia zbawienia wszystkim ludziom ${ }^{23}$. Konkretnym wyrazem tego niesienia zbawienia wszystkim ludziom przez Kościół jako wspólnotę wierzących w Chrystusa jest służba ludzkości przez głoszenie słowa Bożego, sprawowanie sakramentów, bycie dla innych i służbę na rzecz ubogich oraz tych wszystkich, których godność i prawa są łamane w dzisiejszym świecie ${ }^{24}$.

Ważne w nauczaniu II Soboru Watykańskiego jako soboru Kościoła o Kościele i następnie podjęte przez Franciszka jest wreszcie to, że sobór po pierwsze „odkrył na nowo Kościół jako lud Boży i jako communio i ukazał w nowy sposób współodpowiedzialność ludzi świeckich"25. Przy tym wspomniana eklezjologia communio, która znajduje się faktycznie w tle wszystkich obrazów, za pomocą których sobór opisuje istotę Kościoła, domaga się jeszcze ukonkretnienia w życiu i praktyce Kościoła, ponieważ ,,ierpi on obecnie na deficyt komunikacji wewnętrznej i zewnętrznej”"26. Dlatego ,pilnym dezyderatem okazuje się stworzenie pewnej kultury komunikowania się, stylu dialogalnego i struktur komunikowania się, szczególnie struktur synodalnych"27. Postulat ten dotyczy także wprowadzenia w życie Kościoła zakładanej przez sobór kolegialności episkopalnej, tj. dopuszczenia biskupów do uczestnictwa w najwyższej władzy w Kościele czy to na poziomie synodalnym, czy też poziomie lokalnych Episkopatów, a także realizacji w praktyce nowego wymiaru komunii pomiędzy Kościołami partykularny$\mathrm{mi}^{28}$. Po drugie ważne jest to, że sobór ,zrezygnował z doczesnych przywilejów (por. KDK 76) i w jednym z akapitów przedstawił ideał Kościoła ubogiego dla ubogich i z ubogimi (por. KK 8, 3). Niestety, ustępowi temu poświęca się o wiele za mało uwagi i cytuje go uderzająco rzadko"29.

${ }^{23}$ Por. Sobór Watykański II, Konstytucja duszpasterska o Kościele..., 1.

${ }^{24}$ Por. G.L. Müller, Un'esperienza liberante..., s. 20.

${ }^{25}$ W. Kasper, Kościót katolicki..., s. 585.

${ }^{26}$ Tamże, s. 50. W tym miejscu wypada zauważyć, że wspomniany deficyt komunikacji nie dotyczy w sposób bezpośredni okresu pontyfikatu papieża Franciszka, lecz wcześniejszego okresu, ponieważ autor przytoczonego cytatu opublikował swoją książkę w 2012 roku.

${ }^{27}$ Tamże.

${ }^{28}$ Por. A.A. Kasprzak, Kościót a nowoczesność. Rozeznanie pastoralne przemian społeczno-kulturowych we Francji po Soborze Watykańskim II, Kraków 2018, s. 55, 445-446.

${ }^{29}$ W. Kasper, Kościół katolicki..., s. 585. 


\section{Recepcja II Soboru Watykańskiego w nauczaniu papieża Franciszka}

Papież Franciszek, podobnie do wcześniejszych papieży, odważnie wprowadza w życie Kościoła powszechnego naukę i postanowienia II Soboru Watykańskiego, którego celem i zamiarem było, jak zostało to powiedziane, odnowienie Kościoła, ukazanie jego istoty i określenie jego misji we współczesnym świecie. Wymienione kwestie są podejmowane przez papieża Franciszka, który chce „pozostać wierny duchowi soboru i wskazać Kościołowi drogi na przyszłość” ${ }^{30}$. Chce, jak pisze o tym w Adhortacji apostolskiej Evangelii gaudium, „nakreślić drogę duszpasterskiego i misyjnego nawrócenia Kościoła, który nie może pozo-

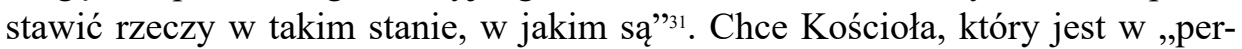
manentnym stanie misji” "32, tzn. Kościoła, w którym wszystko podporządkowane jest misyjności Kościoła i poszukiwaniu przez niego jak najlepszych i najodpowiedniejszych dróg do ewangelizowania współczesnego świata ${ }^{33}$. Przytoczone wypowiedzi pokazują, że główną troską Franciszka jest ukierunkowanie duszpasterskie Kościoła i że w ukierunkowaniu tym widzi on możliwość odnowy Kościoła. Zasadniczym przy tym motywem odnowy Kościoła podejmowanej przez Franciszka, jest - jak przypomina on to za II Soborem Watykańskim i za papieżem Pawłem VI - wierność Jezusowi Chrystusowi i Jego nauczaniu oraz obrazowi Kościoła, jakiego pragnął i jakiego chciał Chrystus ${ }^{34}$.

Wspomniane ukierunkowanie duszpasterskie Kościoła dobrze oddaje określanie przez papieża Franciszka Kościoła jako wspólnoty będącej w drodze i wyruszającej w drogę, do czego pobudza Kościół Słowo Boże, w którym obecny jest dynamizm „wyjścia” i które wzywa wszystkich ochrzczonych do bycia uczniami i misjonarzami Jezusa Chrystusa oraz do wychodzenia na peryferie, ku nowym środowiskom społeczno-kulturalnym ${ }^{35}$. Tym, co przemawia za ujmowaniem Kościoła w perspektywie misyjnej, jest nie tyle racja o charakterze pastoralnym, ile przede wszystkim racja o charakterze teologicznym, ponieważ — jak wyjaśnia to papież Franciszek za Janem Pawłem II — ,zażyłość Kościoła z Jezusem jest zażyłością w «drodze», a komunia przyjmuje kształt komunii misyjnej”"36. Przemawia za tym także przykład samego Jezusa Chrystusa, który głosił Ewangelię wszystkim ludziom, w czym Kościół musi naśladować swojego Mistrza, jeśli chce pozostać Mu wierny. Papież, mówiąc o Kościele jako wspólnocie w dro-

${ }^{30}$ G. Whelan, Il metodo teologico..., s. 133.

${ }^{31}$ Franciszek, Adhortacja apostolska Evangelii Gaudium, 25.

32 Tamże, 25.

33 Por. tamże, 27.

34 Por. tamże, 26.

${ }^{35}$ Więcej na temat Słowa Bożego jako wzywającego do wyjścia i otwarcia się na nowe życie zob. Franciszek, Encyklika Lumen fidei, 9.

${ }^{36}$ Franciszek, Evangelii Gaudium, 23. 
dze, nawiązuje wreszcie do idei Kościoła jako Kościoła pielgrzymującego, który jest — jak podkreśla to II Sobór Watykański — z natury swej misyjny. Misyjność ta, jak wyjaśnia to sobór, bierze swój początek „z misji Syna i misji Ducha, zgodnie z zamysłem Boga Ojca" ${ }^{37}$. Ma także na myśli Lud Boży, który jest ludem pielgrzymującym, a więc ludem w drodze, zmierzającym do swojego ostatecznego celu, jakim jest Bóg. Pielgrzymowanie Kościoła jest w końcu — zdaniem Franciszka — znakiem i wyrazem wspólnotowego charakteru zarówno wiary, jak i życia Kościoła, który jako wspólnota wierzących w Chrystusa pokornie kroczy w obecności Boga, pozwala się Mu prowadzić i jest stale otwarta na przemianę, jakiej wymaga od niej i do jakiej zaprasza ją nieustannie Słowo Boże $e^{38}$.

Wspomniany misyjny charakter Kościoła - jak i to, że jest on wspólnotą w drodze, która zmierza do Boga i jest powołana do tego, by wprowadzać innych ludzi na tę drogę i towarzyszyć im w ich codziennym życiu i w ich doświadczeniach - wymaga od Kościoła, zdaniem Franciszka, wychodzenia na peryferie i „bycia obecnym tam, gdzie najbardziej brakuje światła i życia Zmartwychwstałego $[\ldots]$ oraz wejścia w proces rozeznania" 39 . Rozeznanie to na pierwszym miejscu dotyczy poznania aktualnej sytuacji świata i wyzwań, jakie niesie ona ze sobą, na które Kościół powinien odpowiedzieć. Stąd jednym z istotnych zadań stojących przed Kościołem dzisiaj jest — według Franciszka — poznanie kontekstu, w jakim przychodzi żyć i działać Kościołowi. Innymi słowy, chodzi o badanie znaków czasu, po to aby — jak określił to II Sobór Watykański — odpowiedzieć na nie w świetle Objawienia w sposób zrozumiały i dostosowany do każdego pokolenia ${ }^{40}$. To badanie znaków czasu dotyczy także poznania aktualnej sytuacji Kościoła, by ten nie pozostawiał, jak zostało to powiedziane, rzeczy w takim stanie, w jakim są i stale na nowo podejmował wysiłek zmierzający do wewnętrznej odnowy oraz duszpasterskiego i misyjnego nawrócenia. Dlatego Franciszek korzysta w swojej refleksji teologicznej z metodologii zaproponowanej przez Jana XXIII a następnie zastosowanej przez II Sobór Watykański, zwłaszcza w Konstytucji duszpasterskiej o Kościele w świecie współczesnym, która mówi o badaniu, ocenie i działaniu jako trzech głównych zasadach, na których opiera się i którymi kieruje się nauka społeczna Kościoła. Stosowanie tej metodologii przez Franciszka sprawia, że w swoim nauczaniu podkreśla on i zwraca uwagę na historyczny wymiar wiary i życia chrześcijańskiego. Postrzega ponadto i ujmuje powołanie chrześcijańskie jako budowanie królestwa Bożego, co zakłada współpracę z Bogiem i ściśle łączy się z nadzieją chrześcijańską, która jest otwarta na przyszłość i jej definitywne spełnienie. W związku

\footnotetext{
${ }^{37}$ Sobór Watykański II, Dekret o misyjnej działalności Kościoła Ad gentes divinitus, 2.

${ }^{38}$ Por. Franciszek, Lumen fidei, 13.

${ }^{39}$ Franciszek, Evangelii Gaudium, 30.

${ }^{40}$ Sobór Watykański II, Konstytucja duszpasterska o Kościele..., 4, 11.
} 
z tym wiara chrześcijańska, w której centrum znajduje się osobiste spotkanie z Bogiem i osobą Jezusa Chrystusa, jest — według Franciszka — rzeczywistością ściśle związaną z historią i z nadzieją. Wiara jest bowiem „rzeczywistością doświadczaną i przeżywaną w teraźniejszości, chociaż jej forma została nadana i określona przez doświadczenia z przeszłości, jest także rzeczywistością, która jest ukierunkowana na swoje ostateczne spełnienie"41. Wymaga ona wreszcie od wierzących podjęcia procesu rozeznawania, który pomaga w ukonkretnieniu wiary i sprawia, że działa ona przez miłośćc ${ }^{42}$.

Inną jeszcze ideą, którą Franciszek podejmuje i rozwija za II Soborem Watykańskim, która ma jednocześnie swoje zakorzenienie w praktyce Kościoła latynoamerykańskiego, jest idea Kościoła jako Ludu Bożego, przypominająca prawdę o tym, że wszyscy wierzący tworzą święty Lud Boży, tj. Kościół. Idea ta służy w nauczaniu papieża Franciszka przywróceniu i postawieniu w centrum podmiotowości wszystkich wierzących, na co zwrócił uwagę II Sobór Watykański, który posługuje się tym pojęciem, aby powiedzieć, że wszyscy ochrzczeni mają udział w kapłańskiej, prorockiej i królewskiej godności ludu Bożego ${ }^{43}$. Idea ta wskazuje jednocześnie na przyjęty przez Franciszka punkt widzenia, z którego perspektywy myśli on o Kościele i interpretuje jego doświadczenia. Papież Franciszek rozwija przy tym soborowe rozumienie Kościoła jako Ludu Bożego na podstawie tzw. teologii ludu, która jest jednym z kierunków latynoamerykańskiej teologii wyzwolenia opracowanym w Argentynie przez teologów Lucio Gerę i Rafaela Tello. Jej korzenie sięgają 1966 roku, kiedy to Komisja Episkopatu Argentyńskiego ds. Duszpasterskich wprowadziła pojęcie „lud”, które zakłada posiadanie wspólnej kultury, zakorzenienie we wspólnej historii i angażowanie się na rzecz dobra wspólnego ${ }^{44}$. Ponadto teologia ludu po pierwsze wskazuje na lud jako na „podmiot praktyki historycznej i mówi o tym, że proces inkulturacji kończy się w ludzie, a nie tylko w politycznej awangardzie" ${ }^{45}$. Po drugie, uważa lud wierny, a nie tylko elitę chrześcijańską, za podmiot rozumienia wiary, przez co dowartościowuje katolicyzm ludowy. Po trzecie, przyjmuje jako jedno z głównych zadań praktyki pastoralnej Kościoła to, że jest ona skierowana do ludów, a nie tylko do

${ }^{41}$ A. Downing, La storia e l'orizzonte aperto del futuro [w:] Dal chiodo alla chiave. La Teologia Fondamentale di Papa Francesco, a cura di M. Tenace, Città del Vaticano 2017, s. 87-100, tu: s. 88.

${ }^{42}$ Por. J. Xavier, Dinamiche di fede nel pensiero di papa Francesco [w:] Dal chiodo alla chiave. La Teologia Fondamentale di Papa Francesco, a cura di M. Tenace, Città del Vaticano 2017, s. $15-32$, tu: s. 32.

${ }^{43}$ Por. Sobór Watykański II, Konstytucja dogmatyczna o Kościele..., 9-17.

${ }^{44}$ Por. R. Luciani, La opción teólogico-pastoral del pontificado de Francisco, „Razón y Fe” 1411-1412 (2016), s. 459-471, tu: s. 459-460.

${ }^{45}$ P. de Charentenay, Teologia ludu. Latynoamerykańskie źródło myślenia papieża Franciszka, thum. P. Napiwodzki, „Znak” 754 (2018), s. 20-27, tu: s. 22. 
pojedynczych osób oraz to, że jest ona „promocją inkulturacji i ewangelizacją kultury i kultur ludowych" 46 .

Dlatego Franciszek dowartościowuje lud jako taki, zwłaszcza zaś lud ubogi i religię ludową, ponieważ stanowi ona część spoiwa jednoczącego lud i nadającego mu witalności ${ }^{47}$. Daje mu sens, nadzieję i odwagę do podjęcia walki kontrkulturowej i wysiłku na rzecz zmiany aktualnej sytuacji, ponieważ lud ten tworzą w większości ludzie ubodzy, którzy są marginalizowani, wykluczeni i pozbawieni uczestnictwa w dobrach społeczno-politycznych i ekonomicznych. Lud ubogi to lud najbardziej dotknięty przez aktualny system rozwoju globalnego, którego konsekwencją są pogłębiające się różnice społeczne i coraz większy podział między bogatymi i biednymi krajami, między elitami a pozostałą częścią społeczeństwa. Stąd jedną z istotnych cech Kościoła jako Ludu Bożego jest, zdaniem Franciszka, jego postawa w stosunku do ubogich. Papież dowartościowuje wreszcie religię i pobożność ludową, ponieważ widzi w niej „,autentyczny wyraz spontanicznej działalności misyjnej Ludu Bożego" 48 i uważa ją za „miejsce, w którym można znaleźć Boga" ${ }^{\text {"49 }}$.

Innym ważnym elementem, który tworzy lud i który jest podkreślany przez Franciszka, jest kultura, ponieważ „konstytuuje ona «ciało» ludu, który się rozpoznaje i czyni z niego miejsce spotkania z innymi ludźmi"50. Łączy się ona poza tym z naturą i jest miejscem działania łaski, która zakłada nie tylko naturę, lecz także kulturę, co oznacza, że „Boży dar wciela się w kulturę przyjmujących go ludzi" ${ }^{51}$. Stąd stawanie się i bycie ludem Bożym w historii nie oznacza wcale — zdaniem Franciszka — ,alternatywy w stosunku do bycia częścią jakiegoś konkretnego ludu, lecz [...] bycie ludem, który ma podwójne «my», który czyni widzialnym i doświadczalnym to, że każda kultura może być zamieszkana przez Boga i jest przez Niego kochana" 52 . Lud Boży przybiera zatem — zdaniem Franciszka — „realny ksztalt w ludach zamieszkujących ziemię, z których każdy ma swoją kulturę"53. Papież Franciszek, mówiąc o Ludzie Bożym, przypomina w końcu, że każdy jego członek na mocy otrzymanego chrztu ,stał się uczniem i misjonarzem" ${ }^{4}$, że we wszystkich ochrzczonych „działa uświęcająca moc Du-

46 Tamże.

47 W tym miejscu warto zauważyć, że papież Franciszek używa pojęcia „lud” w trzech znaczeniach: lud jako ubogi, lud, czyli naród, lud — wierny. R. Luciani, La opción ..., s. 465.

${ }^{48}$ Franciszek, Evangelii Gaudium, 122.

49 Tamże, 126.

${ }^{50}$ S. Morra, Un popolo fedele tra i popoli: elementi di ecclesiologia fondamentale [w:] Dal chiodo alla chiave. La Teologia Fondamentale di Papa Francesco, red. M. Tenace, Città del Vaticano 2017, s. 73-86, tu: s. 82.

${ }^{51}$ Franciszek, Evangelii Gaudium, 115.

${ }^{52}$ S. Morra, Un popolo fedele..., s. 82-83.

${ }_{53}$ Franciszek, Evangelii Gaudium, 115.

${ }^{54}$ Tamże, 120. 
cha Świętego, pobudzająca do ewangelizowania" ${ }^{55}$, jak również to, że „lud cały czas ewangelizuje siebie" 56 .

W świetle tego, co zostało powiedziane, widzimy, że w eklezjologii papieża Franciszka ważną rolę odgrywa kategoria Ludu Bożego, obecna także w nauczaniu II Soboru Watykańskiego, która służy papieżowi w dowartościowaniu podmiotowości wszystkich wierzących i przypomnieniu prawdy o tym, że wszyscy wierzący tworzą Kościół, są powołani do misji ewangelizacyjnej i uczestniczą w misji prorockiej gwarantowanej obecnością Ducha Świętego ${ }^{57}$. W ten sposób papież Franciszek przezwycięża także dominującą przez wieki jednostronność nauczania Kościoła, która „szła drogą od Kościoła nauczającego do Kościoła słuchającego" "58. Pokazuje również, że opowiada się za koniecznością ustanowienia wzajemnej relacji pomiędzy dwoma wspomnianymi typami Kościoła, która powinna opierać się na słuchaniu siebie nawzajem, owocnej wymianie i współpracy $^{59}$. Z tego też powodu papież Franciszek, jak zostało to powiedziane, preferuje model Kościoła jako Ludu Bożego, podobnie jak czynił to II Sobór Watykański, który to model został następnie przesunięty jakby na drugi plan, na korzyść modelu Kościoła-komunii. Papież Franciszek dąży także do przesunięcia akcentu z centrum w Kościele na większe dowartościowanie peryferii Kościoła, co zostało zainicjowane przez II Sobór Watykański. Wspomniane przesunięcie akcentu stawia pytanie o strukturę sprawowania autorytetu w Kościele. Konkretnie zaś mówiąc, o to, czy powinno się preferować wyłącznie model komunii, w którym ruch inicjatywy miałby zawsze wypływać z centrum, co odpowiada tradycyjnemu modelowi sprawowania władzy przez papieży, czy może należałoby spojrzeć na Kościół jako komunię, w której ruch dynamiki mógłby zaczynać się w odwrotnym kierunku, tj. od peryferii do centrum Kościoła. Pytanie to dotyczy również tego, jak w praktyce można i należy realizować kolegialny wymiar w Kościele.

Pontyfikat papieża Franciszka pokazuje, że po pierwsze powraca on do kolegialności biskupów zakładanej przez sobór i czyni ją realną ${ }^{60}$. Po drugie dąży do powrotu do jeszcze większego uczestnictwa biskupów w najwyższej władzy w Kościele i jeszcze większej w swoim zakresie synodalnej praktyki Kościoła, tzn. takiej, która funkcjonowała w Kościele zwłaszcza w pierwszym tysiącleciu jego istnienia. Przykładem tego jest to, że papież Franciszek włącza w swoje rządzenie Kościołem i w swoje nauczanie swoich braci w biskupstwie oraz to,

55 Tamże, 119.

56 Tamże, 122.

57 D.I.E. Molina, Francisco el papa del fin de la era Constantiniana?, „Custiones Teológicas/ Medellín-Colombia” 102 (2017), s. 347-370, tu: s. 360.

${ }_{58}$ S. Morra, Un popolo fedele..., s. 84-85.

${ }^{59}$ Por. tamże, s. 85.

${ }^{60}$ Por. D.I.E. Molina, Francisco ..., s. 360. 
że cytuje w swoim nauczaniu dokumenty opracowane przez różne konferencje episkopatów. Świadczy o tym również to, że pozostawia w gestii lokalnych episkopatów kwestię dotyczącą rozeznania i rozwiązywania problemów, jakie pojawiają się na ich terytoriach ${ }^{61}$. W ten sposób dokonuje decentralizacji Kościoła. Dąży także do przezwyciężenia klerykalizacji Kościoła, który to proces został zainicjowany przez II Sobór Watykański ${ }^{62}$. Tym zaś, co pomaga w przezwyciężeniu wspomnianej klerykalizacji Kościoła, jest rozumienie Kościoła jako Ludu Bożego, do którego przynależą nie tylko biskupi i księża, lecz także wszyscy ochrzczeni $^{63}$. Stąd wszyscy wierzący w Chrystusa są powołani do uczestnictwa w misji Kościoła i są za nią odpowiedzialni. Kościół jest bowiem dla Franciszka nie tylko instytucją organiczną i hierarchiczną. Jest on ,przede wszystkim ludem, będącym w drodze do Boga, ludem pielgrzymującym i ewangelizującym, przekraczającym każdy wymiar instytucjonalny, choć takowy jest oczywiście niezbędny" ${ }^{64}$.

Papież Franciszek podejmuje w końcu i rozwija w swoim nauczaniu ideał Kościoła jako Kościoła ubogiego dla ubogich i z ubogimi, o którym wspomniał II Sobór Watykański. Co więcej, stawia go w centrum swojego pontyfikatu wraz z opcją preferencyjną na rzecz ubogich, która powinna charakteryzować - zdaniem Franciszka - życie chrześcijańskie, styl eklezjalny i treść programów duszpasterskich Kościoła. Opcja ta jest bowiem drogą, która prowadzi do komunii z Bogiem i z innymi ludźmi, ponieważ jej podstawą i fundamentem jest wiara w Boga Jezusa Chrystusa, z której wypływa przekonanie o tym, że cierpiące oblicza ubogich są cierpiącymi obliczami Chrystusa. Przyjęcie tej opcji sprawia, że Kościół uznaje ubogich za pierwszy i uprzywilejowany podmiot swojej działalności. Kocha ich, uważa ich za swój cenny skarb i im towarzyszy. Jest otwarty na nowe formy ubóstwa i wykluczenia pojawiające się w świecie oraz próbuje im zaradzić i odpowiedzieć na nie w świetle Ewangelii. Staje się Kościołem misyjnym, który wychodzi na drogi, gdzie znajdują się ludzie ubodzy, wykluczeni i poranieni w różny sposób, by z odwagą głosić im wiarę ${ }^{65}$. Przy czym omawiana opcja preferencyjna Kościoła na rzecz ubogich musi głównie przyjąć, jak podkreśla to Franciszek, „formę uprzywilejowanej i priorytetowej opieki duchowej”"66, ponieważ większość z nich ,potrzebuje Boga, [...] Jego przyjaźni, Jego błogo-

${ }^{61}$ Por. Franciszek, Evangelii Gaudium, 16.

62 Por. D.I.E. Molina, Francisco..., s. 360.

${ }_{63}$ Por. Franciszek, Evangelii Gaudium, 271.

${ }^{64}$ J. Poniewierski, Subiektywne kalendarium pontyfikatu, „Znak” 754 (2018), s. 28-35, tu: s. 30 .

${ }^{65}$ Por. V. Codina, Kościót wykluczonych. Teologia z perspektywy Nazaretu, thum. K.M. Kaproń, Kraków 2018, s. 8-9.

${ }^{66}$ Franciszek, Evangelii Gaudium, 200. 
sławieństwa, Jego Słowa”67. Dlatego Kościół nie może nie ofiarować im „sprawowania sakramentów oraz propozycji drogi rozwoju i dojrzewania w wierze" ${ }^{98}$. $\mathrm{Z}$ drugiej zaś strony, ubodzy są widziani i traktowani przez papieża jako miejsce teologiczne, źródło i inspiracja dla teologii ${ }^{69}$. Związane jest to głównie z tym, że „dzięki własnym cierpieniom znają Chrystusa cierpiącego" ${ }^{\circ 0}$. Stąd Kościół może wiele nauczyć się, zdaniem Franciszka, także od ubogich. Powinien również pozwolić na to, aby był przez nich ewangelizowany, oraz uznać zbawczą moc ich egzystencji i postawić ją w centrum w swojej drogi ${ }^{71}$.

\section{Oryginalność nauczania papieża Franciszka}

Wraz z papieżem Franciszkiem rozpoczął się nowy rozdział w dziejach chrześcijaństwa. Nowość ta jest związana m.in. z nową sytuacją wewnątrz samego Kościoła i z pojawianiem się nowych znaków czasu, a co za tym idzie nowych wyzwań, jakie stoją przed Kościołem dzisiaj, na które papież Franciszek jako następca św. Piotra stara się odpowiedzieć w duchu Ewangelii, co czyni przez „symboliczne gesty swojej duszpasterskiej praktyki i myślowe impulsy zawarte w jego kazaniach i encyklikach"'². Jest ona także wynikiem tego, że świat, w którym żyjemy, zmienia się i wchodzi w nową erę, którą papież Franciszek określa mianem ery postindustrialnej. Zmiana ta dotyczy dokonujących się w świecie zmian o charakterze społecznym i kulturowym, co stanowi nie tylko wyzwanie dla Kościoła, lecz także określa kontekst, w jakim on żyje i działa. Nowość ta dotyczy w końcu samego stylu i sposobu, w jaki Franciszek sprawuje swój urząd, który wydaje się całkowicie odmienny od stylu poprzedników ${ }^{73}$. Ujawniło się to już podczas pierwszego wystąpienia Franciszka tuż po zakończeniu konklawe, kiedy to po wyborze go na papieża poprosił najpierw wiernych zebranych na placu św. Piotra o modlitwę, następnie zaś pochylił głowę i trwał w takiej pozycji przez dłuższą chwilę w milczeniu. W ten sposób zademonstrował swoją wizję papiestwa. „Zaprezentował się nie tyle jako «namiestnik Jezusa Chrystusa», lecz także jako «sługa sług Bożych», który w tej samej mierze co cały Kościół

67 Tamże.

68 Tamże.

69 Por. D.I.E. Molina, Francisco..., s. 367.

70 Franciszek, Evangelii Gaudium, 198.

71 Tamże. Więcej na temat rozumienia Kościoła jako Kościoła ubogiego i dla ubogich zob. D. Gardocki, Kościót ubogi i dla ubogich jako wyzwanie i zadanie stojace przed Kościołem dzisiaj, „Studia Bobolanum” 3 (2015), s. 5-21, tu: s. 9-19.

72 T. Halik, Pięć lat..., s. 11.

73 D. Kozłowska, Zmyst Franciszka, „Znak” 754 (2018), s. 1. 
potrzebuje błogosławieństwa Bożego" " . Pokazał także, że potrzebuje wspólnoty Kościoła, żeby móc trwać przed Bogiem i że nie traktuje jej jedynie jako „przedmiotu” ewangelizacji. Mówił poza tym o sobie jako o „biskupie Rzymu”, co wcale nie oznacza, że nie uważa siebie za papieża, lecz to, że papież „nie jest sam ponad Kościołem, ale jest w nim jako ochrzczony wśród ochrzczonych, a w kolegium biskupów jako biskup wśród biskupów, powołany jednocześnie jako następca Piotra do kierowania Kościołem rzymskim, który przewodniczy w miłości wszystkim Kościołom"7s.

Wspomniana nowa wizja papiestwa, jaką proponuje Franciszek, jest związana niewątpliwie także z imieniem, jakie przyjął on po wyborze na następcę św. Piotra. Określa ono w pewnym sensie program jego pontyfikatu, w którego centrum znajduje się troska zarówno o powierzony mu Kościół, jak i o wszystkich ludzi, zwłaszcza zaś o ludzi ubogich, chorych, wykluczonych, którzy są ofiarami procesu globalizacji i dominującego w świecie systemu neoliberalnego. Świadectwem tej szczególnej troski papieża o ubogich była odbyta przez niego pierwsza podróż apostolska na Lampedusę, gdzie spotkał się z uchodźcami z Afryki i ,prosił Boga o wybaczenie «dla tych, którzy zamknęli się w dobrobycie, który znieczula serce, [oraz] dla tych, którzy przez swoje decyzje na poziomie światowym stworzyli sytuacje, prowadzące do takich dramatów»" ${ }^{\text {" }}$. Jest nim także ustanowienie przez Franciszka Światowego Dnia Ubogich, który traktuje on jako „okazję do uruchomienia wyobraźni miłosierdzia, przeciwstawienia się kulturze odrzucenia i budowania w sobie postawy solidarności" ${ }^{\prime 7}$. Jest nim wreszcie to, że papież chce Kościoła ubogiego i dla ubogich oraz to, że podkreśla ważność dla Kościoła opcji preferencyjnej na rzecz ubogich, która widziana jest przez Franciszka jako probierz a zarazem istotny element wiarygodności Kościoła. Opcja ta jest bowiem opcją ewangeliczną, gdyż znajduje się w Ewangeliach, które mówią o tym, że to sam Jezus uczynił z ubogich uprzywilejowanych adresatów swojego przepowiadania. Co więcej, Ewangelie przedstawiają Jezusa jako człowieka ubogiego, w czym Kościół, jeśli chce pozostać wierny Jezusowi, powinien Go także naśladować. Dlatego realizacja tej opcji przez Kościół jest znakiem i potwierdzeniem obecności królestwa Bożego, które Jezus przyszedł przynieść ${ }^{78}$. Opcja ta wymaga w końcu od Kościoła tego, by był „Kościołem «wyruszającym w drogę», [...] Kościołem otwartych drzwi. Wychodzącym ku innym, aby dotrzeć do ludzkich peryferii $[\ldots]$ i towarzyszyć człowiekowi, który pozostał na skraju drogi”"79.

\footnotetext{
74 J. Poniewierski, Subiektywne kalendarium ..., s. 29.

75 Tamże.

76 Tamże, s. 33.

77 Tamże, s. 35.

78 Por. Franciszek, Evangelii Gaudium, 48.

79 Tamże, 46,
} 
By był zawsze „otwartym domem Ojca" ${ }^{80}$. Jedną z konsekwencji przyjęcia omawianej opcji przez Kościół jest to — zdaniem Franciszka — że wszelkie decyzje podejmowane przez Kościół, co dotyczy w sposób szczególny decyzji o charakterze pastoralnym, muszą mieć na uwadze ubogich. Inną jeszcze konsekwencją jest to, że przynagla ona Kościół do bycia i stawania się Kościołem misyjnym, tj. Kościołem wychodzącym poza siebie i wchodzącym na drogi, gdzie znajdują się dzisiaj ludzie ubodzy, wykluczeni i poranieni w różny sposób ${ }^{81}$.

Omówiona opcja preferencyjna na rzecz ubogich, podkreślana przez Franciszka, ściśle łączy się z tematem miłosierdzia, który przenika całość papieskiego nauczania i stanowi klucz do odczytania tego pontyfikatu. Franciszek uważa bowiem miłosierdzie nie tylko za jeden z przymiotów Boga, lecz także za imię Boga i traktuje miłosierdzie jako „zasadę hermeneutyczną w odniesieniu do hierarchii wartości nie po to, aby zmieniać lub kwestionować nauczanie Kościoła czy przykazania, lecz aby rozumieć je i wypełniać właściwie, to jest w duchu Ewangelii" " 2 . Wyrazem tego jest określanie przez Franciszka Kościoła jako „szpitala polowego". Metaforę tę można traktować jako nowy model Kościoła proponowany przez papieża ${ }^{83}$. W tym nowym modelu akcent zostaje położony na miłosierdzie jako na istotną cechę a zarazem postawę, jaką powinien kierować się Kościół i wcielać ją w życie. Kościół jest bowiem powołany do tego — zdaniem Franciszka - by być „miejscem bezinteresownego miłosierdzia, [...] w którym wszyscy mogą doświadczyć przebaczenia" ${ }^{" 4}$. Miejscem, gdzie opatruje się rany i leczy choroby, do czego zachęca Kościół sam Jezus w przypowieści o dobrym Samarytaninie, w której jest zawarty i opisany wzorzec drogi Kościoła. Przykład dobrego Samarytanina uczy Kościół myślenia o sobie samym z perspektywy ludzi znajdujących się i leżących przy drodze. Zachęca i jednocześnie przynagla Kościół do troski o każdego człowieka, w szczególności zaś tego, który znajduje się w jakiejkolwiek potrzebie, jak również tego, który przeżywa dramat braku sensu, będący konsekwencją odrzucenia wiary. Namawia także do tego, by całą działalność Kościoła przenikała i kształtowała postawa miłosierdzia i by postawę tę traktował on jako podstawową zasadę i normę swojej działalności. Papież Franciszek, mówiąc i wskazując na miłosierdzie jako najważniejszą zasadę i normę działalności Kościoła, powraca do tego, co zdaniem Pawła VI inspirowało duchowość II Soboru Watykańskiego. Inspiracja ta pochodziła z przypowieści o dobrym Samarytaninie, która mówi o miłosierdziu i bezinteresownej miłości. Wskazuje jednocześnie na służbę, jako na właściwą drogę Kościoła, a co za tym

80 Tamże, 47.

${ }^{81}$ Por. tamże, 46, 97.

82 J. Poniewierski, Subiektywne kalendarium..., s. 32.

${ }^{83}$ Por. D.I.E. Molina, Francisco..., s. 363. Zob. także, Jan Paweł II, Encyklika Dives in misericordia, Watykan 1996, rozdz. VII.

${ }^{84}$ Franciszek, Evangelii Gaudium, 114. 
idzie na dyspozycyjność w praktykowaniu miłosierdzia i solidarności w stosunku do każdego człowieka, w sposób szczególny zaś w stosunku do osób najbardziej potrzebujących $^{85}$. Użyta w końcu przez papieża Franciszka metafora Kościoła jako „szpitala polowego” służy mu do „wyjaśnienia stylu i ducha, który powinien ożywiać ewangelizację Nowego Ludu Bożego" "86.

$\mathrm{Z}$ drugiej zaś strony metafora ta odsłania w pewnym sensie nowość nauczania papieża Franciszka na temat Kościoła, ponieważ woli on mówić o misji Kościoła i o tym, co powinien on czynić, aniżeli zajmować się kwestiami teoretycznymi na temat tego, czym jest Kościół. W ten sposób papież Franciszek dokonuje w pewnym sensie zmiany w eklezjologii, której istota polega na ,przejściu od tego, jak należy rozumieć Kościół (teologia) do tego, jak powinien on działać (praktyka pastoralna)" ${ }^{" 87}$. Zmiana ta związana jest z tym, że Franciszka interesuje przede wszystkim Kościół ad extra i jego misyjność. Pragnie, by cały Kościół był misyjny i wszystko było w nim podporząakowane misji, co wymaga od Kościoła podjęcia nawrócenia, bez którego nie ma mowy o prawdziwej reformie i odnowie Kościoła. Wymaga także powrotu do radykalizmu Ewangelii i wcielania go w życie. Nie chce natomiast Kościoła, który zajmuje się tylko sobą i ,zamyka się w gąszczu obsesji i procedur" ${ }^{\prime 8}$ czy ,koncentruje się jedynie na tym, co było w przeszłości i z nostalgią wspomina epoki dawnego blasku i świetności" ${ }^{89}$. Co więcej, woli od takiego Kościoła „Kościół poturbowany, poraniony i brudny, bo wyszedł na ulice" ${ }^{90}$. Kościól, który jest w stanie permanentnej misji. Celem wspomnianej zmiany w eklezjologii, jakiej dokonuje papież Franciszek, nie jest przeobrażenie dotychczasowej nauki o Kościele, lecz jedynie pogłębienie i zastosowanie nauki o Kościele w odnowiony sposób, by służyła ona działalności pastoralnej Kościoła i ją ożywiała ${ }^{11}$. Nowość nauczania papieża Franciszka na temat Kościoła polega zatem na patrzeniu na Kościół z perspektywy misji i misyjności Kościoła, ponieważ Kościół nie istnieje dla siebie, lecz jest Kościołem dla ludzi.

$Z$ tego też względu papież Franciszek dąży do przywrócenia równowagi między tym, co o Kościele mówi Konstytucja dogmatyczna o Kościele II Soboru Watykańskiego, a tym, co mówi o nim Konstytucja duszpasterska o Kościele w świecie wspótczesnym. W tym dążeniu ujawnia się jednocześnie nowość nauczania Franciszka, ponieważ interesuje go przede wszystkim relacja Kościoła ze światem, co zostało zainicjowane przez soborową Konstytucję duszpasterska o Koś-

${ }^{85}$ G. Gutiérrez, La spiritualità dell'evento conciliare [w:] Povera per i poveri. La missione della Chiesa, a cura di G.L. Müller, Città del Vaticano 2014, s. 237-274, tu: s. 263, 273-274.

86 D.I.E. Molina, Francisco..., s. 370.

87 J. Corkery, Francesco..., s. 143.

88 Franciszek, Evangelii Gaudium, 49.

89 V. Codina, Kościół wykluczonych..., s. 9.

90 Franciszek, Evangelii Gaudium, 49.

91 J. Corkery, Francesco..., s. 145. 
ciele w świecie wspótczesnym, w czym różni się od swoich poprzedników, których zasadniczy kierunek myślenia o Kościele wyznaczała koncepcja komunii. Dokonana przez Franciszka zmiana perspektyw nie oznacza wcale tego, że ignoruje on eklezjologię zawartą w Konstytucji dogmatycznej o Kościele, lecz jedynie to, że chce zwrócić przede wszystkim uwagę na misyjny wymiar Kościoła ${ }^{92}$. Bowiem Kościół opisany przez Konstytucje dogmatyczna o Kościele, tj. Kościół ad intra, jest równocześnie Kościołem ad extra, o którym mówią zarówno Konstytucja duszpasterska o Kościele w świecie współczesnym, jak i papież Franciszek.

Tym, co dodatkowo wskazuje na zakorzenienie i rozwijanie myślenia i nauczania papieża Franciszka w duchu Konstytucji duszpasterskiej o Kościele w świecie współczesnym, jest posługiwanie się przez niego metodą indukcyjną i egzystencjalną. Chociaż była ona stosowana przez II Sobór Watykański, zwłaszcza w wymienionej konstytucji, to jednak nie była zasadniczo używana przez wcześniejszych papieży, którzy preferowali posługiwanie się metodą dedukcyjną ${ }^{93}$. Dlatego papież Franciszek za punkt wyjścia swojej refleksji teologicznej przyjmuje konkretną sytuację historyczną Kościoła i świata i zmierza do określenia znaków czasu, by udzielić na nie odpowiedzi w świetle Objawienia i Tradycji Kościoła. W tym celu posiłkuje się wspomnianą metodą, która dowartościowuje dialog i rozeznanie, co wywołuje nierzadko sprzeciw wśród osób oczekujących od nauczania papieskiego „jasnych i abstrakcyjnych stwierdzeń na tematy dotyczące zwłaszcza kwestii natury moralnej"’4. Służy ona także papieżowi do podkreślenia historycznego wymiaru wiary i życia chrześcijańskiego, jak również wskazania na kontekstualny charakter Objawienia i nauczania Kościoła. Objawienie bowiem — jak wyjaśnia to papież chociaż zawiera prawdy i mówi o prawdach, które są niezmienne, to równocześnie trzeba pamiętać o tym, że prawdy te zostały wyrażone za pomocą języka danego czasu, ponieważ Objawienie wydarzyło się w konkretnym kontekście historyczno-społecznym. Stąd papież zwraca uwagę na to, że ,prawdy teologiczne nie istnieją w sposób abstrakcyjny w sobie i dla siebie, lecz [...] są włączone w konkretny kontekst historyczny, «wcielone w niego»" ${ }^{95}$, jak również na to, że prawdy te podlegają uwarunkowaniom historycznym ${ }^{96}$. Nie traktuje poza tym doktryny chrześcijańskiej, lub „lepiej naszego jej rozumienia i wyrażania jako systemu zamkniętego, pozbawionego zdolności do rodzenia pytań, dyskusji”"97, lecz jako „rzeczywistość żywą, która umie niepokoić i ożywiać, ma czułe ciało: doktryna chrześcijańska

92 Por. tamże, s. 146.

93 Por. F. Patsch, Rivelazione, contesto, veritá. Il Magistero di Papa Francesco in tempo di transizione [w:] Dal chiodo alla chiave. La Teologia Fondamentale di Papa Francesco, a cura di M. Tenace, Città del Vaticano 2017, s. 45-72, tu: s. 57.

94 G. Whelan, Il metodo teologico..., s. 129.

95 F. Patsch, Rivelazione..., s. 50.

96 Por. tamże, s. 51.

97 Franciszek, Adhortacja apostolska Gaudete et exsultate, 44. 
nosi bowiem imię Jezus Chrystus" ${ }^{\text {"98 }}$. Jest to związane także z tym, że po pierwsze, „Bóg nas nieskończenie przerasta, zawsze jest zaskoczeniem i nie my decydujemy o tym, w jakich okolicznościach historycznych możemy Go spotkać" 99 . Po drugie, że „prawdę, którą otrzymujemy od Pana, możemy pojąć jedynie w sposób niedoskonały. Z jeszcze większą trudnością udaje się nam ją wyrazić"100.

Przytoczone wypowiedzi odsłaniają różnicę, jaka istnieje w podejściu do teologii i w sposobie jej traktowania przez Franciszka i jego poprzednika Benedykta XVI. Różnica ta jest dostrzegalna w tym, że podczas gdy

Benedykt XVI rozwijał swoje teksty z precyzją naukową i zwracał uwagę na szczegóły, to Franciszek jest mniej wymagający z punktu widzenia akademickiego, ponieważ uważa, że nasze myśli muszą być zawsze czymś niepełnym, co trzeba coraz bardziej doskonalić; że system zamknięty, który nie pozostawia przestrzeni na kreatywność, jest karykaturą tego, czym jest teologia ${ }^{101}$.

Jest ona dostrzegalna także w tym, że „chociaż papież Franciszek nie jest profesjonalnym teologiem, tylko duszpasterzem, to jednak przyjęty przez niego styl pomaga przeformułować teologię, promuje styl teologiczny, który jest mistagogiczny, symboliczny, narracyjny i duszpasterski" ${ }^{102}$. Dlatego papież Franciszek nie używa języka koncepcyjnego, lecz ,języka, który odwołuje się do kategorii osobistych i relacyjnych, wciąga i inspiruje słuchacza. Jest językiem pasterza" ${ }^{103}$. I chociaż język ten niekiedy szokuje i wprawia w zakłopotanie, to jednak słowa, które on wypowiada są słowami Ewangelii i podobnie jak sama Ewangelia mogą stać się przedmiotem zgorszenia ${ }^{104}$. Słowa te

docierają jednak do ludzi od razu, skracają dystans, przywołując — tak jak czynił Jezus w swoich przypowieściach — obrazy i sytuacje życia codziennego. Towarzyszą im gesty będące ich interpretacją albo zajmujące ich miejsce: gesty czułości, solidarności, które lepiej niż mowa mogą wyrazić uczucie bliskości, zrozumienia ${ }^{105}$.

Język, który preferuje papież Franciszek jest w końcu językiem konkretnym, realistycznym, bogatym w obrazy.

${ }^{98}$ F. Patsch, Rivelazione..., s. 70.

${ }^{99}$ Franciszek, Gaudete et exsultate, 41.

100 Tamże, 43.

101 J. Corkery, Francesco..., s. 148.

102 V. Codina, Kościót wykluczonych..., s. 10.

103 Tamże, s. 149.

104 Więcej na temat zarzutów, jakie są kierowane pod adresem Franciszka i jego nauczania zob.

R.R. Reno, Dlaczego...

105 J. Poniewierski, Subiektywne kalendarium..., s. 35. 
Przykładem są rozważania papieskie poświęcone wyjaśnieniu tego, czym jest wiara chrześcijańska, zawarte w Encyklice Lumen fidei, gdzie papież opisuje istotę wiary chrześcijańskiej dzięki odwołaniu się do różnych obrazów, takich jak: „droga”, „wędrówka”, „projekt współpracy z Bogiem”, „,budowanie i przygotowanie nowego miasta", , nowe Jeruzalem”. Dostrzegalne jest to również w homiliach głoszonych przez Franciszka zwłaszcza w domu św. Marty i w udzielanych przez niego wywiadach. Tym, co charakteryzuje całość nauczania papieskiego a zarazem ukazuje jego nowość, jest posługiwanie się przez Franciszka nie tylko obrazami, lecz także metaforami. Jedną z takich metafor jest wspominane już opisanie Kościoła jako „szpitala polowego”. Inną metaforą jest porównanie Kościoła do „zamku z piasku”, za pomocą którego papież mówi o grożącym Kościołowi niebezpieczeństwie wówczas, gdy ten zamknie się w sobie i nie będzie wychodzić poza siebie, by głosić Ewangelię i szukać dobra wszystkich ludzi ${ }^{106}$. Kolejnymi metaforami, jakimi posługuje się Franciszek, są „zapach owiec”107 czy też „zapach Ewangelii”" ${ }^{108}$. Pierwsza służy papieżowi do ukazania prawdy na temat ewangelizatorów jako tych, którzy powinni być blisko ludzi, towarzyszyć im i uczestniczyć w ich życiu i doświadczeniach. Druga z kolei służy wskazaniu na ducha i sposób podejmowanej przez chrześcijan ewangelizacji oraz treści przez nich przekazywanej, która powinna być z jednej strony wolna od wszelkich ideologii i zniekształceń, z drugiej zaś przekazywać samą istotę Ewangelii.

Omawiana oryginalność nauczania papieża Franciszka przejawia się także w tym, że posiada on dar formułowania uderzających i lotnych fraz takich jak na przykład: „konfesjonał nie powinien być salą tortur” ${ }^{109}$ czy „Kościół nie jest urzędem celnym” Oryginalność ta przejawia się również w tym, że papież w swoim nauczaniu odwołuje się do i podkreśla rolę i znaczenie wyobraźni w życiu chrześcijańskim, ponieważ pozwala ona, jego zdaniem, w sposób twórczy naśladować Chrystusa i ,pojednać to, co wydaje się niemożliwe do pogodzenia ze sobą, jak Bóg i człowiek, czas i wieczność, principia i rzeczywistość” ${ }^{111}$. Stanowi ona poza tym ,nieodzowny środek, który prowadzi wierzących do prawdziwego pocieszenia duchowego" 112 . Przy czym posługiwanie się wyobraźnią musi być połączone, zdaniem Franciszka, z koniecznością rozeznawania, ponieważ także zło zwodzi ludzi za pośrednictwem wyobraźni, która tworzy wówczas rzeczywistość nieprawdziwą lub całkowicie ją zaciemnia.

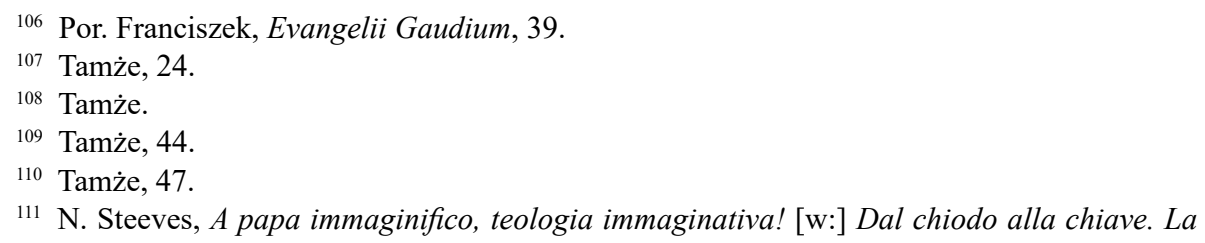
Teologia Fondamentale di Papa Francesco, a cura di M. Tenace, Città del Vaticano 2017, s. 101112, tu: s. 105.

112 Tamże, s. 107. 
Wspomniana potrzeba rozeznawania jest kolejnym elementem, który odsłania nowość nauczania Franciszka. Celem rozeznawania, które jest bliskie papieżowi i które jak sam o nim mówi, odgrywało i stale odgrywa istotną rolę w jego życiu, najpierw jako jezuity, następnie zaś biskupa a obecnie następcy św. Piotra, jest ostatecznie odkrycie woli Bożej w konkrecie życia. Pomaga ono bowiem nie tylko w poznawaniu siebie i dojrzewaniu duchowym, lecz także w ukierunkowaniu swojego życia, by stawało się ono „kontemplacyjne w działaniu”. Jest „narzędziem walki do lepszego podążania za Panem”"113 i tym, co „prowadzi do samego źródła życia"114. Jest ,prawdziwym wyjściem ku tajemnicy Boga [...], pomaga nam żyć misją, do jakiej nas powołał dla dobra braci”"115. Wymaga wreszcie postawy słuchania i otwierania się na natchnienia i światło pochodzące od Ducha Świętego, by umieć rozeznać, czy rozwiązania z przeszłości są właściwe i przydatne także dzisiaj. Duch Święty bowiem i tylko On ,potrafi przeniknąć najciemniejsze zakamarki rzeczywistości i uwzględnić wszystkie jej niuanse, aby nowość Ewangelii objawiła się w innym świetle" $" 116$.

Dlatego papież Franciszek preferuje dialog i rozeznanie, co jest dostrzegalne w tym, że po pierwsze, swoje rozumienie na temat rządzenia Kościołem opiera w dużej mierze na koncepcji kolegialności zawartej w Konstytucji dogmatycznej o Kościele. Po drugie, przyznaje większą władzę konferencjom poszczególnych episkopatów. Po trzecie, zaleca podjęcie dialogu pomiędzy małżonkami katolickimi i pasterzami, jak i towarzyszenie oraz podjęcie procesu rozeznania z tymi, którzy żyją w powtórnych związkach ${ }^{117}$. Po czwarte, ,nie przyjmuje «jednolitego» podejścia w nauczaniu moralnym i społecznym, co stanowi problem dla tych, którzy oczekują na ten temat jasności wypowiedzi w stylu Jana Pawła II" ${ }^{118}$. Po piąte, nie zamierza dawać szczegółowych rozwiązań dotyczących konkretnych problemów współczesnego świata, lecz proponuje dialog, którego celem jest wspólne poszukiwanie dróg, na których problemy te mogą zostać rozwiązane.

\section{Podsumowanie}

Tym, co charakteryzuje całość pontyfikatu papieża Franciszka, jest „,pragnienie pokazania światu nowości i świeżości Ewangelii”" ${ }^{119}$ oraz uświadomienie i przypomnienie tego, co jest w niej najistotniejsze. Papieżowi chodzi zatem o powrót

\footnotetext{
113 Franciszek, Gaudete et exsultate, 169.

114 Tamże, 170.

115 Tamże, 175.

116 Tamże, 173.

117 Por. G. Whelan, Il metodo teologico..., s. 126-130.

118 J. Corkery, Francesco..., s. 149.

119 J. Poniewierski, Subiektywne kalendarium ..., s. 35.
} 
do samego źródła, ponieważ w nim upatruje możliwość odnowienia Kościoła jako wspólnoty wierzących w Chrystusa, która została powołana przez Niego po to, aby przepowiadać Dobrą Nowinę i być w Chrystusie „niejako sakramentem, czyli znakiem i narzędziem wewnętrznego zjednoczenia z Bogiem i jedności całego rodzaju ludzkiego" ${ }^{120}$. Powrót ten oznacza także konieczność podjęcia przez Kościół rozeznania pomiędzy tym, co stanowi centrum i istotę przepowiadania chrześcijańskiego a tym, co jest w nim drugorzędne, jak i tym, co w przeciągu historii uległo deformacji i oddaliło się od prostoty przepowiadania Jezusa ${ }^{121}$. Wskazuje on ponadto na potrzebę misyjnego i pastoralnego nawrócenia Kościoła, a także na konieczność przyjęcia przez Kościół „opcji misyjnej” i „dynamizmu misyjnego", który sprawia, że Kościół nie będzie koncentrować się na sobie i zajmować tylko sobą, lecz będzie stawał się Kościołem w drodze, Kościołem otwartych drzwi, Kościołem wychodzącym na peryferie i poszukującym odpowiednich dróg do ewangelizowania współczesnego świata.

Papież Franciszek przypomina zatem w swoim nauczaniu to, co od zawsze charakteryzowało Kościół i chrześcijaństwo. Czyni to w nowy sposób i za pomocą nowego języka, gestów i sposobu życia. Chce, podobnie do swoich poprzedników na stolicy Piotrowej, służyć wierze i ją umacniać. Dlatego nie zmienia ani też nie chce zmieniać tego, co stanowi samą istotę wiary chrześcijańskiej ${ }^{122}$. Chce natomiast Kościoła, który będzie „wzrastał w rozumieniu Ewangelii i w rozeznawaniu dróg Ducha" ${ }^{123}$. Stąd podkreśla wagę i potrzebę stałej postawy rozeznawania - dotyczy to zarówno Kościoła jako całości, jak i poszczególnych jego członków, w czym ujawnia się duchowość jezuicka Franciszka, jego „doświadczenie wynikające z praktyki «rozeznawania duchów» i odwaga do rzetelnej konfrontacji z rzeczywistością oraz do kreatywnego szukania nowych dróg"124.

Wspomniane bycie jezuitą — zakonnikiem — jest także tym, co odróżnia Franciszka od jego poprzedników, którzy byli księżmi diecezjalnymi. Dlatego w swoim rządzeniu Kościołem papież stosuje praktyki typowo jezuickie jak na przykład powołanie ścisłej grupy kardynałów konsultorów, którzy pochodzą z różnych odległych miejsc świata a nie z Kurii Rzymskiej, w czym przejawia się także pewna forma decentralizacji rządzenia Kościołem. Mianuje kardynałami biskupów, którzy mają doświadczenie w służbie ubogim. Jest wreszcie wierny jako jezuita przyjętej przez XXXII Kongregację Jezuitów opcji na rzecz wiary i sprawiedliwości ${ }^{125}$. Stąd kładzie akcent w swoim nauczaniu na: 1) sprawiedli-

${ }^{120}$ Sobór Watykański II, Konstytucja dogmatyczna o Kościele..., 1.

121 Por. D.I.E. Molina, Francisco..., s. 366.

122 Por. O.G. de Cardedal, Los vuelcos en la Iglesia. De Ratzinger a Bergolio, „Veritas” 30 (2014), s. 129-161, tu: s. 156.

${ }^{123}$ Franciszek, Evangelii Gaudium, 45.

124 T. Halik, Pięć lat..., s. 10.

125 J. Corkery, Francesco..., s. 146-148. 
wość jako na prymat życia społecznego i politycznego; 2) prymat życia; 3 ) miłosierdzie chrześcijańskie; 4) ubóstwo i troskę o ubogich; 5) obecność w miejscach, gdzie brakuje miłości i panuje dehumanizacja i przemoc. Tym zatem, co wpływa na nauczanie Franciszka i jednocześnie pozwala poznać źródło jego nowości, jest także historia jego życia i to skąd pochodzi ${ }^{126}$.

Papież Franciszek łączy w swojej osobie „radosną franciszkańską duchowość biedy i wolności z jezuicką odwagą, by podążać za najbardziej złożonymi problemami i wciąż kultywować kulturę «rozeznawania duchów»"127.

\section{The mission of the Church - the extraordinary ordinariness of the teaching of Pope Francis}

\section{Summary}

With Pope Francis a new chapter has begun in the history of the Church. This newness refers to the new internal situation of the Church, new "signs of time", and new challenges which the Church has to face. Through the symbolic gestures of his pastoral practice and the directions indicated in his homilies and encyclical letters Francis responds to these challenges in the spirit of the Gospel.

His whole pontificate is characterized by the profound desire to impart the newness and freshness of the Gospel as well as what constitutes the core of its teaching. In this endeavor of returning to the sources, he sees the possibility of renewal of the Church. This entails a discernment of what constitutes the center and core of the Christian proclamation versus what is secondary, as well as how Jesus' teaching has been distorted and deformed over the centuries. Francis speaks about the necessity of the apostolic and pastoral conversion of the Church. The Church has to undertake the "option for mission" and "apostolic dynamism". She must go to the peripheries.

In his teaching Pope Francis imparts the traditional doctrine of the Church. But he does it in a new way, using new language, new gestures and a new way of life. Like his predecessors, he wants to serve the faith. He does not wish to change what constitutes the core of the Christian faith. But he wants the Church to grow in the understanding of the Gospel as well as in the discernment of the ways of the Spirit. Therefore, he emphasizes the constant need for the attitude of discernment. This is what he has learned above all from Ignatian spirituality and his pastoral experience: "the discernment of the spirits".

\section{Keywords}

Church of the poor, preferential option for the poor, mercy, renewal, mission, discernment, dialogue

\footnotetext{
126 Por. O.G. de Cardedal, Los vuelcos en la Iglesia..., s. 157.

127 T. Halik, Pięć lat..., s. 9.
} 


\section{Słowa kluczowe}

Kościół ubogi, opcja preferencyjna na rzecz ubogich, miłosierdzie, odnowa, misyjność, rozeznanie, dialog

\section{Bibliografia}

Cardedal G.O. de, Los vuelcos en la Iglesia. De Ratzinger a Bergolio, „Veritas” 30 (2014), s. $129-161$.

Charentenay P. de, Teologia ludu. Latynoamerykańskie źródło myślenia papieża Franciszka, thum. P. Napiwodzki, „Znak” 754 (2018), s. 20-27.

Codina V., Kościół wykluczonych. Teologia z perspektywy Nazaretu, tłum. K.M. Kaproń, Kraków 2018.

Corkery J., Francesco, erede e innovatore: un Papa Argentino e gesuita nella tradizione post-conciliare [w:] Dal chiodo alla chiave. La Teologia Fondamentale di Papa Francesco, a cura di M. Tenace, Città del Vaticano 2017, s. 135-150.

Downing A., La storia e l'orizzonte aperto del futuro [w:] Dal chiodo alla chiave. La Teologia Fondamentale di Papa Francesco, a cura di M. Tenace, Città del Vaticano 2017, s. 87-100.

Draguła A., Kościół Franciszka, Kościół Benedykta, „Więź” 2 (2013), s. 15-25.

Franciszek, Adhortacja apostolska Evangelii Gaudium, Watykan 2013.

Franciszek, Adhortacja apostolska Gaudete et exsultate, Watykan 2018.

Franciszek, Encyklika Lumen fidei, Watykan 2013.

Gardocki D., Kościół ubogi i dla ubogich jako wyzwanie i zadanie dla Kościoła dzisiaj, „Studia Bobolanum” 3 (2015), s. 5-21.

Gutiérrez G., La spiritualità dell'evento conciliare [w:] Povera per i poveri. La missione della Chiesa, a cura di G.L. Müller, Città del Vaticano 2014, s. 237-274.

Halik T., Pięć lat z Franciszkiem, tłum. K. Ćwiek-Rogalska, „Znak” 754 (2018), s. 6-11. Jan Paweł II, Encyklika Dives in misericordia, Watykan 1996.

Kasper W., Kościół Katolicki. Istota, rzeczywistość, posłannictwo, thum. G. Rawski, Kraków 2014.

Kasprzak A.A., Kościót a nowoczesność. Rozeznanie pastoralne przemian społeczno-kulturowych we Francji po Soborze Watykańskim II, Kraków 2018.

Kozłowska D., Zmyst Franciszka, „Znak” 754 (2018), s. 1.

Luciani R., El Papa Francisco y la teología del pueblo, Madrid 2016.

Luciani R., La opción por los pobres desde una Iglesia pobre y para los pobres, ,Medellin" 168 (2017), s. 347-373.

Luciani R., La opción teólogico-pastoral del pontificado de Francisco, „Razón y Fe” 1411-1412 (2016), s. 459-471.

Łoziński B., Zrozumieć Franciszka, „Gość Niedzielny” 39 (2018), s. 34-36. 
Matwiejuk K., Papieże przełomu drugiego i trzeciego tysiaclecia, Siedlce 2018.

Molina D.I.E., Francisco el papa del fin de la era Constantiniana?, „Custiones Teológicas/Medellín-Colombia” 102 (2017), s. 347-370.

Morra S., Un popolo fedele tra i popoli: elementi di ecclesiologia fondamentale [w:] Dal chiodo alla chiave. La Teologia Fondamentale di Papa Francesco, a cura di M. Tenace, Città del Vaticano 2017, s. 73-86.

Müller G.L., Un'esperienza liberante: impulsi per la teologia Europea [w:] Dalla parte dei poveri. Teologia della liberazione, teologia della chiesa, a cura di G.L. Müller, G. Gutièrrez, trad. M. Castagnaro, G. Mazzillo, Padova 2013, s. 19-44.

Patsch F., Rivelazione, contesto, veritá. Il Magistero di Papa Francesco in tempo di transizione [w:] Dal chiodo alla chiave. La Teologia Fondamentale di Papa Francesco, a cura di M. Tenace, Città del Vaticano 2017, s. 45-72.

Pawlina K., Eklezjologia papieża Franciszka, „Studia Bobolanum” 1 (2014), s. 13-20.

Poniewierski J., Subiektywne kalendarium pontyfikatu, „Znak” 754 (2018), s. 28-35.

Reno R.R., Dlaczego mam kłopot z Franciszkiem, wywiad przeprowadzony w rozmowie z M. Burzykiem i M. Jędrzejkiem, „Znak” 754 (2018), s. 12-17.

Seweryniak H., Franciszkowe marzenie o Kościele „w drodze”, „Homo Dei” 2 (2014), s. $58-73$.

Sobór Watykański II, Konstytucje, Dekrety, Deklaracje, Poznań 2002.

Steeves N., A papa immaginifico, teologia immaginativa! [w:] Dal chiodo alla chiave. La Teologia Fondamentale di Papa Francesco, a cura di M. Tenace, Città del Vaticano 2017, s. 101-112.

Xavier J., Dinamiche di fede nel pensiero di papa Francesco [w:] Dal chiodo alla chiave. La Teologia Fondamentale di Papa Francesco, a cura di M. Tenace, Città del Vaticano 2017, s. 15-32.

Whelan G., Il metodo teologico di papa Francesco [w:] Dal chiodo alla chiave. La Teologia Fondamentale di Papa Francesco, a cura di M. Tenace, Città del Vaticano 2017, s. $113-133$. 